\title{
The Influence of Work Motivation and Interpersonal Communication on Social Competence of Public Elementary School Teachers
}

Sriwahyuningsih

Guru SDN 008 Bukit Kapur, Dumai City, 28882, Indonesia

\section{ARTICLE INFO}

Article history:

Received: 15 June 2021

Revised: 14 Jan 2022

Accepted: 16 Jan 2022

Published online: 24 Jan 2022

Keywords:

Work Motivation

Interpersonal Communication

Teacher Social Competence

\begin{abstract}
A B S T R A C T
This study aims to determine the effect of work motivation and interpersonal communication on the social competence of teachers. The population of this study were teachers of public elementary schools in Cluster IV, Bukit Kapur District, Dumai City. Sampling was done by simple random sampling technique, the sample was set at 91 people. The data was collected by using a questionnaire technique and then analyzed using several linear regression equations and the proof of the hypothesis using the $t$ test, $F$ test, and the coefficient of determination (R2). The results of the t-test of the work motivation variable have a significant effect on the teacher's social competence. Interpersonal communication variables have a significant effect on the social competence of teachers. The results of statistical tests (Test F), simultaneously work motivation and interpersonal communication have a significant effect on the social competence of teachers at SDN Gugus IV Bukit Kapur, Dumai City. Based on the $\mathrm{t}$ and $\mathrm{F}$ tests, the hypothesis is accepted.
\end{abstract}

\section{Introduction}

Education is one of the fields that plays an important role in building a complete human being. The purpose of education in general is to improve the quality of human resources through improving the quality of education. Schools are the foremost institutions in carrying out the process of improving the quality of human resources through education. Principals and teachers play an important role as a driving force in schools to achieve organizational goals in schools. Every school has organizational goals that must be achieved. The principal as a determinant of the direction of school policy and as a driver in the school, must be able to cooperate with all stakeholders to achieve the goals of the school organization.

\footnotetext{
* Corresponding author. 
Everyone believes that teachers have a very big role in the success of learning in schools. Teachers play a very important role in helping the development of students to realize their life goals optimally. This belief arises because humans are weak creatures, which in their development always need other people, from birth, even at the time of death. All of this shows that everyone needs other people in their development, as well as students when parents enroll their children in school, at that time they also place their hopes on the teacher, so that their children can develop optimally. To achieve this goal, a teacher who has high competence is needed. One of the things that teachers must have is social competence.

\section{Social Competence}

Social competence is the ability of teachers as part of the community to communicate and interact effectively with students, education staff, parents/guardians of students and the community around Damsar in Janawi (2019). In the Law of the Republic of Indonesia (UU RI) No. 14 article 10 concerning Teachers and Lecturers it is stated that teacher social competence is the ability of teachers to communicate and interact effectively and efficiently with students, fellow teachers, parents/guardians of students and the community. Social competence According to Suharsimi, in Ashsiddiqi (2012) social competence means that teachers must have the ability to communicate socially with students, fellow teachers, principals and the community. According to Mulyasa in Putri (2017), states that social competence is "the ability of teachers as part of the community. According to Sagala in Entin Suhartini (2011), teacher social competence is reflected in the ability of a teacher to communicate effectively and interact socially or adapt well to all school members and the surrounding community.

Social competence is the ability of individuals to plan strategies to interact with others in the reality of social changes that occur around them, Priamikova in Marzoan (2017). The social competence proposed by Buchari Alma in Rahmawati (2018) is the ability of teachers to communicate and interact effectively with the school environment and outside the school environment. Individuals who have social competence are able to obtain positive responses from others and are skilled in forming close and mutually supportive relationships. Smart \& Sanson in Rika Aulia Purnama (2017). Based on some of the opinions of the experts above, it can be concluded that social competence is the ability of a teacher to communicate effectively and interact socially or adapt well to all school members and the surrounding community.

\section{Work Motivation}

According to Robert L. Mathis and John H. Jakson in Moenir (2010) motivation derived from the word motive is a will or desire that arises in a person that causes that person to act. According to Dimyati in Ardiana (2017) motivation is a mental impulse that moves and directs human behavior. According to Winardi in Wibowo (2013), explaining work motivation is a potential force that exists within a human being, which can be developed by a number of external forces which 
essentially revolve around monetary rewards, and non-monetary rewards that can affect performance results positively or positively. negative, which depends on the situation and conditions faced by the person concerned. According to Bafadal in Sukendar (2013) suggests that work motivation is a person's desire (desire) and willingness (willingness) to make decisions, act and use all his psychic, social and physical abilities in order to achieve certain goals.

Other factors affect work motivation such as principals' leadership skills, teacher conditions, and teacher professional certification as factors in improving the quality of teachers' work motivation because they have a positive and significant effect on Dewi in Umami (2021). According to Yawan (2016) work motivation is encouragement both from within (intrinsic) and from outside (extrinsic) which causes a teacher to be enthusiastic in teaching because of a strong desire from within him, namely his needs are met. Based on the description above, it can be concluded that teacher work motivation is something that can create enthusiasm or encouragement to work individually or in groups towards work in order to achieve goals. Teacher work motivation is a condition that makes teachers have the will or need to achieve certain goals through the implementation of a task.

\section{Interpersonal Communication}

According to Rahmat in Aziz (2017), says that communication is a process that develops from impersonal to interpersonal, meaning that there is an increase in relationships between communicators, often interpersonal meetings begin with talks on general issues, such as age, place of residence., education from the region and so on. According to Suciati in Diana (2020) human life cannot be separated from communication, both verbal and non-verbal. Mulyana in Dayanti (2014) said that interpersonal communication is communication between people face to face, which allows each participant to capture the reactions of others directly, both verbally and non-verbally. According to Bochner in Ngalimun (2018), interpersonal communication is the process of delivering messages by one teacher and receiving messages by another teacher or a small group of teachers, with various impacts and with opportunities to provide immediate feedback. Rogers in Muhammad Yodiq (2016) means that interpersonal communication or interpersonal communication is word of mouth communication that occurs in face-to-face interactions between several individuals.

According to Arni Muhammad in Oktariana (2020) Interpersonal communication is the process of exchanging information between a person and at least another person or usually between two people who can be directly identified. According to Sawaludin in Elfridauli (2018) interpersonal communication also affects the social dimension in the organization, making communication effective and teachers working harder to be responsible for their work. So, it can be concluded that interpersonal communication is a process of human activity consisting of two or more people in which there is a process of sending messages from one person to another and is an interaction between individuals who look intact and directly with each other in conveying and communicating. receive real messages in order to inspire each other's participation which is measured. This study generally aims 
to examine and analyze the effect of work motivation and interpersonal communication together on the social competence of teachers in public elementary schools in clusters of four, Bukit Kapur sub-districts, Dumai City.

\section{Methodology}

This type of research was Ex post facto research with a quantitative research approach. Kerlinger in Ibrahim (2018). Ex post facto research is a systematic empirical investigation that does not control independent variables directly because the existence of these variables has occurred or because these variables basically cannot be manipulated.

The research was carried out in a State Elementary School in cluster IV, Bukit Kapur District, Dumai City with a total of 4 schools. The type of data used was quantitative data. Quantitative data was data obtained in the form of numbers from the results of the questionnaire. The data obtained from the questionnaire then be processed statistically using the SPSS application. The population of this research was all public elementary school teachers in cluster IV, Bukit Kapur District, Dumai City with the total population is 117 people.

Determination of the sample in this study used a simple random sampling technique, namely the technique of taking samples from the population at random without regard to the existing stsrata in the population Sugiono (2013). Sampling was carried out evenly to each school so that all respondents had the same opportunity as the research sample. In determining the sample size using the Slovin formula (Herlina, 2018):

$$
n=\frac{N}{1+N e^{2}}
$$

The data collection technique used in this research was a questionnaire or research questionnaire in the field. Questionnaires or questionnaires adapted from previous research which is for the $\mathrm{X} 1$ variable (Work Motivation) adapted from (Uno, 2016), the X2 variable (Interpersonal Communication) was adapted from previous research (Herlina, 2018), while for the social competence variable used APKG (Teacher Performance Assessment Tool) on teacher social competence. The implementation of the instrument trial was held to test the validity and calculation of the reliability of each statement item. The alternatives provided by the researchers in this study were for positive item answers, Very often (SS), Often (S), Sometimes (KK), Rarely (JR), and Never (TP), with a value scale of 5, 4, 3, 2 , 1. Then the answers to items are negative, Very Often (SS) Often (S), Sometimes (KK), Rarely (JR), and Never (TP), with a value scale of 1, 2, 3, 4,5 . Reliability test using SPSS 23 by comparing the Cronbach alpha number with the provision of a minimum Cronbach alpha value of 0.6. This means that if the Cronbach alpha value is greater than 0.6 then the questionnaire is reliable or consistent. And conversely, if the Cronbach alpha value is less than 0.6 then the questionnaire is declared unreliable or inconsistent. By calculating the SPSS 
program, the reliability value for each work motivation variable $=0.963$; interpersonal communication $=0.971$. Because the Cronbach Alpha value is above 0.60 , the measuring instrument is reliable or has met the reliability requirements.

\section{Results and Discussion}

\section{Data Description}

The data that is processed in this study is to describe the effect of work motivation and interpersonal communication on the social competence of teachers in cluster IV, Bukit Kapur District. The description of the research data is based on testing a sample of as many as public schools in cluster IV, Bukit Kapur sub-district.

\section{Description of Teacher Social Competence Data (Y)}

The results of calculations on the data on the teacher's social competence variable, the results obtained are as in table 1.

Table 1. Statistics Description of Social Competence

\begin{tabular}{lll}
\hline Variabel & Description & Statistical Results \\
\hline & Valid & 91 \\
& mean & 84,21 \\
Teacher Social Competence & median & 85,00 \\
& mode & 83 \\
& Std. Deviation & 4,722 \\
& Minimum Value & 77 \\
& Maximum Value & 93 \\
\hline
\end{tabular}

Table 1 explains that the teacher's social competence variable obtained a mean value which is the average value of all data. The teacher's social competence variable of 84.21 is in a good interpretation, this is in accordance with the conversion of the PKG value of 76-90 which is in the good category, the median value (median) of the teacher's social competence variable is 85.00 and the most frequent value (mode) of the teacher's social competence variable is 83 . For the highest value (maximum) obtained from the teacher's social competence variable of 93 and the lowest value (minimum) ) obtained by the teacher's social competence variable is 77 . Thus the value for the work motivation variable is in the good category. The categories for the interval criteria refer to Permenpan No.16 of 2009 which can be seen in table 2. The distribution category of variable frequency distribution based on the data interval of Social Competence can be seen in table 3 . Based on table 3 , it can be seen that 11 respondents with a percentage of $12.1 \%$ have social competence in the Very Good category. 80 respondents with a percentage of $87.9 \%$ have social competence in the Good category. Thus, it can be concluded that the social competence of teachers in cluster IV, Bukit Kapur sub-district is in the Good category. 
Table 2. Conversion of PKG Value in accordance with Permenpan RB. No. 16

TH. 2009

\begin{tabular}{cc}
\hline Interval & Category \\
\hline $91-100$ & Very good \\
$75-90$ & Good \\
$61-75$ & enough \\
$51-60$ & Currently \\
$\leq 50$ & Not enough \\
\hline
\end{tabular}

Source permepan no 16 of 2009

Table 3. Description of the Frequency of Social Competence

\begin{tabular}{cccc}
\hline Interval & Category & Frequency & Percentage \\
\hline $91-100$ & Very good & 11 & $12,1 \%$ \\
$76-90$ & Good & 80 & $87,9 \%$ \\
$61-75$ & Enough & 0 & 0 \\
$51-60$ & Currently & 0 & 0 \\
$\leq 50$ & Not enough & 0 & 0 \\
\hline Total & & 91 & $100 \%$ \\
\hline & & \multicolumn{2}{c}{ Source, Processed Data 2021 }
\end{tabular}

\section{Description of Work Motivation Data (X1)}

The results of the calculation of the data on the Work Motivation variable, the results obtained are as in table 4.

Table 4. Statistical Calculation of Work Motivation Data (X1)

\begin{tabular}{ccc}
\hline Variabel & Description & Statistical Results \\
\hline \multirow{3}{*}{ Work motivation } & Valid & 91 \\
& Mean & 137,4 \\
& Median & 139 \\
& Mode & 117 \\
& Std. Deviation & 12,491 \\
& Minimum Value & 111 \\
Maximum Value & 157 \\
\hline
\end{tabular}

Source, Processed data 2021

Table 4 explains that the Work Motivation variable has a mean value which is the average value of all data. The Work Motivation Variable of 137.49 is in the very high category according to the interval between the value of work motivation, the value of 134-160 is in the very high category. The median value (median) of the Work Motivation variable is 139 and the most frequent value (mode) of the Work Motivation variable is 117 . For the highest (maximum) value obtained from the Work Motivation variable, 157 and the lowest (minimum) value obtained by the Movation variable. Work is 111 . Thus the value for the work motivation variable is in the high category. The categories for the interval interpretation criteria are divided into 4 categories, namely very high, high, medium, low, and very low. Thus the distribution of variable frequency distribution categories based on work motivation data intervals can be seen in table 5 . 
Table 5. Description of Work Motivation Frequency

\begin{tabular}{cccc}
\hline Interval & Category & Frequency & Percentage \\
\hline $134-160$ & Very high & 58 & $67,7 \%$ \\
$107-133$ & Tall & 33 & $36,3 \%$ \\
$80-106$ & Currently & 0 & 0 \\
$53-79$ & Low & 0 & 0 \\
$26-52$ & Very low & 0 & 0 \\
\hline & & 91 & $100 \%$ \\
\hline & Total & \multicolumn{2}{c}{ Source, Processed Data 2021 }
\end{tabular}

Based on table 5, it can be seen that 58 respondents with a percentage of $67.7 \%$ have work motivation in a very high category, 33 respondents with a percentage of $36.3 \%$ have work motivation in a high category. Thus, it can be concluded that the work motivation of teachers in cluster IV, Bukit Kapur sub-district is in the very high category.

\section{Description of Interpersonal Communication Data (X2)}

The results of calculations on the data on interpersonal communication variables can obtained are as in table 6 .

Table 6. Statistics Description of Interpersonal Communication

\begin{tabular}{ccc}
\hline Variabel & Description & Statistical Results \\
\hline & Valid & 91 \\
& Mean & 142,33 \\
Interpersonal Communication & Median & 143 \\
& Mode & 143 \\
& Std. Deviation & 12,446 \\
& Minimum Value & 117 \\
& Maximum Value & 162 \\
\hline
\end{tabular}

Source, Processed Data 2021

Table 6 explains that the Interpersonal Communication variable obtained a mean value which is the average value of all data. Interpersonal Communication Variable of 142.33 is in the very high category according to the interval value of interpersonal communication, the value of $139-165$ is in the very high category. The median value (median) of the Interpersonal Communication variable is 143 and the most frequent value (mode) of the Interpersonal Communication variable is 143. The highest value (maximum) obtained from the Interpersonal Communication variable is 162 and the lowest value (minimum) obtained is the Communication variable. Interpersonal is 117 . Thus the score for the interpersonal communication variable is in the very high category. The categories for the interval interpretation criteria are divided into 4 categories, namely very high, high, medium, low, and very low. 
Thus the distribution of variable frequency distribution categories based on interpersonal communication data intervals can be seen in table 7 .

Table 7. Description of Interpersonal Communication Frequency

\begin{tabular}{|c|c|c|c|}
\hline Interval & Category & Frequency & Percentage \\
\hline $139-165$ & Very High & 60 & $65,9 \%$ \\
\hline $112-138$ & Tall & 31 & $34,1 \%$ \\
\hline $85-111$ & Currently & 0 & 0 \\
\hline $58-84$ & Low & 0 & 0 \\
\hline$\geq 57$ & Very Low & 0 & 0 \\
\hline \multicolumn{2}{|c|}{$\mathrm{T}$} & 91 & $100 \%$ \\
\hline
\end{tabular}

Source,Processed Data 2021

Based on table 7, it can be seen that 60 respondents with a percentage of $65.9 \%$ interpersonal communication with a very high category, 31 respondents with a percentage of $34.1 \%$ interpersonal communication with a high category. Thus, it can be concluded that the interpersonal communication of teachers in cluster IV, Bukit Kapur sub-district belongs to the very high category.

\section{Inferential Statistical Analysis}

Inferential statistical analysis is a method that deals with making conclusions about the population based on the behavior of the sample. This inferential statistical analysis was conducted to see the contribution between variables in accordance with the formulation of the problem, objectives and research hypotheses, by first looking at the relationship between variables, it is necessary to test requirements for correlation in the form of normality and linearity tests.

The normality test of the data in this study used the Kolmogorov-Smirnov test, with a significant level used as a rule to accept or reject the normality test or the presence or absence of a data distribution $=0.05$. To accept or reject the hypothesis by comparing the significant value of the variable with $=0.05$. As for the decision rule, the data is declared to be normally distributed if the significant value $>=0.05$. The results of the normality test of the three variables can be seen in table 8. The significance value of each of these variables is $>0.05$, which means $\mathrm{HO}$ is accepted. Thus the requirements of the regression analysis are met.

\section{Linearity Test}

The linearity test aims to determine whether the variable data has a linear relationship or not significantly. This test is used as a prerequisite for parametric statistics, especially in correlation analysis or linear regression which is included in the associative hypothesis. The linearity test uses SPSS version 23 program assistance. The linearity test on the variables of work motivation (X1), interpersonal communication (X2), and teacher social competence (Y) can be seen in table 9. 
Table 8. Normality Testing of Work Motivation, Interpersonal Communication on Teacher Social Competence

\begin{tabular}{|c|c|c|c|c|}
\hline \multicolumn{5}{|c|}{ One-Sample Kolmogorov-Smirnov Tes } \\
\hline & & $\begin{array}{c}\text { Work } \\
\text { Motivation }\end{array}$ & $\begin{array}{l}\text { Interpersonal } \\
\text { Communication }\end{array}$ & Social Competence \\
\hline \multicolumn{2}{|l|}{$\mathrm{N}$} & 91 & 91 & 91 \\
\hline \multirow{2}{*}{$\begin{array}{l}\text { Normal } \\
\text { Parameters }^{\mathrm{a}, \mathrm{b}}\end{array}$} & Mean & 137,49 & 142,33 & 143,04 \\
\hline & $\begin{array}{l}\text { Std. } \\
\text { Deviation }\end{array}$ & 12,491 & 12,446 & 13,560 \\
\hline \multirow{2}{*}{$\begin{array}{l}\text { Most Extreme } \\
\text { Differences }\end{array}$} & Absolute & ,083 & ,090 & ,086 \\
\hline & $\begin{array}{l}\text { Positive } \\
\text { Negative }\end{array}$ & $\begin{array}{r}, 063 \\
-, 083\end{array}$ & $\begin{array}{r}, 083 \\
-, 090\end{array}$ & $\begin{array}{r}, 077 \\
-, 086\end{array}$ \\
\hline \multicolumn{2}{|c|}{$\begin{array}{l}\text { Test Statistic } \\
\text { Asymp. Sig. (2-tailed) }\end{array}$} & $\begin{array}{r}, 083 \\
.156^{\mathrm{c}}\end{array}$ & $\begin{array}{l}, 090 \\
.066^{\mathrm{c}}\end{array}$ & $\begin{array}{l}.086 \\
.095^{\mathrm{c}}\end{array}$ \\
\hline \multicolumn{5}{|c|}{$\begin{array}{l}\text { a. Test distribution is Normal. } \\
\text { b. Calculated from data. } \\
\text { c. Lilliefors Significance Corre }\end{array}$} \\
\hline
\end{tabular}

Source: Processed Data 2021

Table 9. Linearity Test Results of Variances for Work Motivation Variables (X1), Interpersonal Communication (X2), and Teacher Social Competence (Y)

\begin{tabular}{lc}
\hline & Sig \\
\hline Teacher Social Competence-Work Motivation (X1) & 0,119 \\
Teacher Social Competence-Interpersonal Communication (X2) & 0,113 \\
\hline
\end{tabular}

Based on Table 9. the significance value (sig) of Deviation from linearity of teacher social competence $(\mathrm{Y})$ with work motivation $(\mathrm{X} 1)$ is 0.119 , greater than 0.05 . So it can be concluded that there is a linear relationship between the variables of teacher social competence (Y) and work motivation (X1). Furthermore, the significance value (sig) deviation from linearity of teacher social competence (Y) with interpersonal communication (X2) is 0.113 which is greater than 0.05 . So it can be concluded that there is a linear relationship between the variables of teacher social competence $(\mathrm{Y})$ and interpersonal communication (X2). The linear relationship between the teacher's social competence variable (Y) and interpersonal communication (X2) can be seen in Figure 1. 


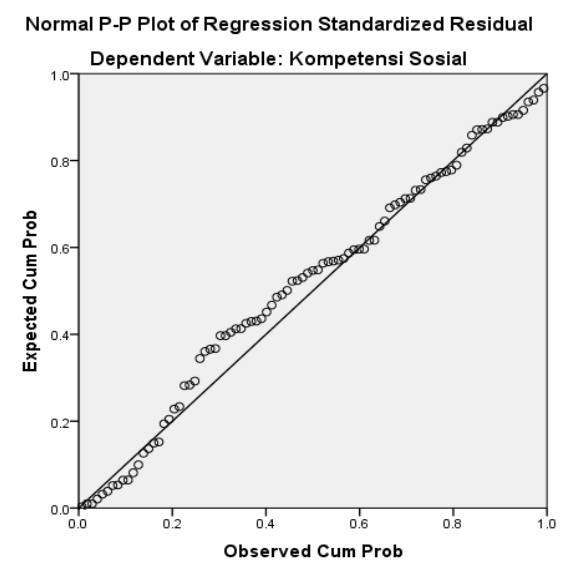

Figure 1. P-P Plot regression variable Work Motivation (X1) and Interpersonal Communication on Teacher Social Competence (Y).

Based on Figure 1, it is obtained that the distribution of data shows the level of normality, that the data on work motivation, interpersonal communication on the social competence of teachers spread in a linear line. This explains that the data are in normal existence.

\section{Multicollinearity Test}

The multicollinearity test aims to determine whether there is an intercorrelation or a strong relationship between independent variables or independent variables. The multilinearity test can be seen in two ways, namely by looking at the Tolerance value and the Variance Inflation Factor (VIF). The results of the Regression Model Multicollinearity Test can be seen in table 10.

Table 10. Multicollinearity Test Results of Regression Model

\begin{tabular}{lccl}
\hline \multicolumn{1}{c}{ Model } & Tolerance & Vif & Description \\
\hline Work Motivation & 0,722 & 1,387 & There is no multicollinearity \\
Interpersonal Communication & 0,722 & 1,37 & There is no multicollinearity \\
\hline
\end{tabular}

Source: Processed Data 2021

Based on table 10, it can be seen that the VIF value for all independent variables is not more than 10, and the tolerance value is also close to 10. Based on these results, it can be concluded that all independent variables consisting of work motivation and interpersonal communication have no symptoms of multicollinearity.

\section{Research Hypothesis Testing}

\section{Multiple Linear Regression Analysis}

Multiple regression analysis was tested using the SPSS 23 program. The coefficients of work motivation (x1) and interpersonal communication (x2) variables on social competence (Y) can be seen in table 11 . 
Table 11. Coefficient of Work Motivation (X1) and Interpersonal Communication (X2) Variables on Social Competence (Y)

\begin{tabular}{ccc}
\hline Model & B & Sig \\
\hline (Konstanta) & 44,908 & 0,000 \\
Work Motivation & 0,225 & 0,000 \\
Interpersonal Communication & 0,472 & 0,000 \\
\hline
\end{tabular}

Based on table 11 about the coefficient of interpersonal communication variable (X2) with teacher social competence (Y), obtained a value of $\mathrm{a}=44.908$ and $\mathrm{b} 1=$ 0.225 and $\mathrm{b} 2=0.472$ so that the regression equation becomes $\mathrm{Y}=44.908+0.225$ +0.472 and the equation can be interpreted that the effect of both variables are positive and significant. The statistical results indicate that work motivation and interpersonal communication at the constant 44,908 have the effect of increasing teacher performance by 0.225 and 0.472 for elementary school teachers in cluster IV, Bukit Kapur sub-district, Dumai City.

The statistical results show that together work motivation and interpersonal communication have a positive and significant influence on teachers' social competence, meaning that the better work motivation and interpersonal communication, the better the social competence of State Elementary School teachers in cluster IV, Bukit Kapur sub-district, Kota Dumai. On the other hand, the worse the work motivation and interpersonal communication, the worse the social competence of public elementary school teachers in cluster IV, Bukit Kapur sub-district, Dumai City.

From table 10 the coefficients of work motivation variables (X1) and interpersonal communication (X2) with teacher social competence (Y) also obtained probability values where these values are used to determine whether the hypothesis is accepted or rejected. If the probability value is greater ( $\operatorname{sig}>0.05$ ), then $\mathrm{HO}$ is accepted and $\mathrm{Ha}$ is rejected, meaning that it is not significant. Meanwhile, if the probability value is smaller (sig 0.05), then $\mathrm{HO}$ is rejected and $\mathrm{Ha}$ is accepted which means it is significant. From table 4.23 above, it can be seen that the sig probability value is 0.000 . The value of sig. $0.000<0.05$ means $\mathrm{H} 0$ is rejected and $\mathrm{Ha}$ is accepted so that work motivation (X1) and interpersonal communication $(\mathrm{X} 2)$ have a significant effect on teacher social competence $(\mathrm{Y})$.

Based on the coefficient table of work motivation (X1) and interpersonal communication (X2) variables on teacher social competence (Y) it can be interpreted that the hypothesis that reads there is a positive influence between work motivation (X1) and interpersonal communication (X2) on school social competence (Y) the base in cluster IV, Bukit Kapur District, Dumai City was accepted.

This finding is also supported by research conducted by Yani (2016) which found that work motivation has a positive and significant effect on teacher competence at SMK Negeri 1 Pasuruan. This is because motivation is related to the fulfillment of life needs, such as psychological needs. Psychological needs are related to the 
fulfillment of needs in terms of clothing, food, shelter, physical and spiritual. Furthermore, the research conducted by Sulastri (2018). The results show that there is a positive relationship between interpersonal communication between teachers and social competence. This is indicated by the correlation coefficient rxy of 0.660 and $t$ count $=9.273$ which is greater than $t$ table at $=0.05$, which is 1.67. The pattern of the relationship between the two variables, expressed by the linear regression equation $=28.67+0.60 \mathrm{X}$. This equation provides information that the average change in one interpersonal communication score between teachers is followed by a change in one unit of social competence score of 0.60 at a constant 28.67. Furthermore, the research conducted by Alam (2012), The Effect of Professional Competence and Social Competence of Accounting Economics Teachers on the Learning Achievement of High School Students in Pati City. The results showed that the criteria for professional competence was high $(80.67 \%)$, while the social competence of teachers was very high $(85.00 \%)$. There is a significant influence between professional competence and social competence of teachers, either partially or simultaneously on student achievement. This is shown from the average student achievement in accounting economics subjects on good criteria (74.90).

From several studies that have been conducted by several researchers, it can be proven that social competence can improve human behavior. Teacher social competence is reflected in the ability of a teacher to communicate effectively and interact socially or adapt well to all school members and the surrounding community.

\section{Coefficient of Determination Test}

Testing the hypothesis that was accepted positively and significantly, it is also necessary to know how much the contribution of interpersonal communication variables (X2) to social competence (Y). For this, it can be concluded in table 12.

Table 12. The Influence of Work Motivation (X1) and Interpersonal Communication (X2) Variables on Teacher Social Competence (Y)

\begin{tabular}{lcccc}
\hline $\mathbf{R}$ & R Square & Sig,F Change & Influence (\%) & Interpretation \\
\hline 0,565 & 0,320 & 0,000 & $32 \%$ & Low \\
\hline & & Predictors: (Constant), interpersonal communication
\end{tabular}

In table 12 , it is obtained that $R$ square $\left(r^{\wedge} 2\right)=0.320$ or $32 \%$, which means that the influence of work motivation (X1) and interpersonal communication (X2) variables on the social competence of elementary school teachers (Y) in cluster IV, Bukit Kapur District, Dumai City is 32. \% while the remaining 68\% is determined by other factors that are not part of this study. Thus, it can be concluded that the contribution of work motivation (X1) and interpersonal communication $(\mathrm{X} 2)$ variables to social competence $(\mathrm{Y})$ has a low interpretation or low contribution. 


\section{Conclusion}

From the results of this study, the conclusions are formulated as follows:

1. Work motivation has a positive and significant effect on the social competence of elementary school teachers in cluster IV, Bukit Kapur District, Dumai City. Thus, it is clear that work motivation has a positive and significant effect on the social competence of teachers. Which means that if work motivation increases, the teacher's social competence will also increase.

2. Interpersonal communication has a positive and significant effect on the social competence of teachers in cluster IV, Bukit Kapur District, Dumai City. Thus it is clear that interpersonal communication has a positive and significant effect on the social competence of teachers. Which means that if interpersonal communication increases, the teacher's social competence will also increase.

3. Work motivation and interpersonal communication simultaneously have a positive and significant effect of $32 \%$ on the social competence of teachers in cluster IV, Bukit Kapur District, Dumai City. The higher the work motivation and interpersonal communication possessed by the teacher, the higher the social competence of teachers in cluster IV, Bukit Kapur District, Dumai City. This indicates that to improve the social competence of teachers in cluster IV, Bukit Kapur District, Dumai City, it can be achieved through increasing work motivation and interpersonal communication simultaneously.

\section{Acknowledgement}

The authors would like to thank the principal, teachers, and administration in cluster IV, Bukit Kapur District, Dumai City, whose school was used as the research sample.

\section{References}

Alami, A. (2012). Pengaruh Kompetensi Profesional Dan Kompetensi Sosial Guru Ekonomi Akuntansi Terhadap Prestasi Belajar Siswa Sma Di Kota Pati (Doctoral dissertation, Universitas Negeri Semarang).

Ardiana, T. E. (2017). Pengaruh motivasi kerja guru terhadap kinerja guru akuntansi SMK di Kota Madiun. Jurnal Akuntansi dan Pajak, 17(02).

Ashsiddiqi, M. H. (2012). Kompetensi sosial guru dalam pembelajaran dan pengembangannya. Ta'dib: Jurnal Pendidikan Islam, 17(01), 61-71.

Aziz, M. A. (2017). Pengaruh Komunikasi Interpersonal Guru terhadap Motivasi Berprestasi dalam Mewujudkan Kinerja Guru. Jurnal Pendidikan UNIGA, 11(1), 9-17.

Dayanti, R. W. (2014). Pengaruh Komunikasi Interpersonal, Ketelitian (Conscientiousness), Dan Kepuasan Kerja Terhadap Kinerja Kepala 
Sekolah Paud Di Kecamatan Medan Deli (Doctoral dissertation, UNIMED).

Diana, R., Ahmad, S., \& Wahidy, A. (2020). Pengaruh Motivasi Kerja dan Komunikasi Interpersonal Terhadap Kinerja Guru. Jurnal Pendidikan Tambusai, 4(3), 1828-1835.

Elfridauli, E. (2018). Pengaruh Budaya Organisasi Dan Komunikasi Interpersonal Terhadap Sikap Kerja Guru SMP Swasta. Kelola: Jurnal Manajemen Pendidikan, 5(1), 96-106.

Herlina. (2018). Pengaruh Komunikasi Interpersonal dan Motivasi Kerja Terhadap Kinerja Guru MTs Negeri di Kota Palembang Universitas PGRI Palembang.

Ibrahim, A. (2018). Metode Santri Aktif Belajar Membaca dan Menulis Al-Qur'an dengan Tajwid Aplikatif.

Janawi. (2019). Kompetensi Guru Cita Guru Profesional. Bandung. Alfabeta.

Marzoan, M., \& Hamidi, H. (2017). Permainan tradisional sebagai kegiatan ekstrakurikuler untuk meningkatkan kompetensi sosial siswa. Journal AnNafs: Kajian Penelitian Psikologi, 2(1), 62-82.

Moenir. (2010). Manajemen Pelayanan Umum di Indonesia. Jakarta. Bumi Aksara.

Ngalimun. (2018). Komunikasi Interpersonal. Yogyakarta. Pustaka Pelajar

Oktarina, E., Makhdalena, M., \& Caska, C. (2020). Pengaruh Komunikasi Interpersonal Dan Motivasi Kerja Terhadap Kinerja Guru Sma Negeri Se Kota Pekanbaru. Jurnal JUMPED (Jurnal Manajemen Pendidikan), 8(1), 84-94.

Purnama, R. A., \& Wahyuni, S. (2017). Kelekatan (attachment) pada ibu dan ayah dengan kompetensi sosial pada remaja. Jurnal Psikologi UIN Sultan Syarif Kasim, 13(1), 30-40.

Putri, S. D., \& Suwatno, S. (2017). Pengaruh kompetensi pedagogik dan kompetensi sosial terhadap prestasi belajar siswa pada mata pelajaran pengantar administrasi perkantoran kelas $\mathrm{X}$ administrasi perkantoran di SMK Negeri 1 Subang. Jurnal Pendidikan Manajemen Perkantoran (JPManper), 2(2), 113-123.

Rahmawati, A., \& Nartani, C. I. (2018). Kompetensi Sosial Guru Dalam Berkomunikasi Secara Efektif Dengan Siswa Melalui Kegiatan Pembelajaran Bahasa Indonesia Di Sd Negeri Rejowinangun 3 Kotagede Yogyakarta. Trihayu, 4(3), 259031.

Sugiono. (2013). Metode Penelitian Administrasi R\&D. Bandung. Alfabeta.

Suhartini, E. (2011). Analisis Faktor-Faktor yang Mempengaruhi Kompetensi Guru pada Sekolah Menengah Kejuruan Rintisan Sekolah Bertaraf Internasional di Kabupaten Indramayu. Skripsi. Jakarta: Universitas Indonesia.

Sukendar, N. C. E. (2013). Pengaruh keterampilan kepemimpinan kepala sekolah dan motivasi kerja guru terhadap kinerja guru smp negeri di sub rayon 03 kabupaten jepara. Jurnal Manajemen Pendidikan, 2(1), 1-18.

Sulastri, S. (2018). Korelasi Komunikasi Interpersonal Antar Guru Dengan Kompetensi Sosial (Studi di SMA Negeri 5 Kota Serang) (Doctoral dissertation, Universitas Islam Negeri" SMH" Banten). 
Umami, W., Rifma, R., \& Syahril, S. (2021). The Effects of Work Motivation and Communication Condition on Elementary Teachers' Performance. Journal of Educational Sciences, 5(4), 727-739.

Undang-Undang Republik Indonesia (UU RI) No.14

Uno, H. B. (2016). Teori Motivasi dan Pengukurannya. Jakarta. Bumi Aksara

Wibowo, B. K. (2013). Pengaruh Komunikasi Internal, Motivasi Kerja, Dan Loyalitas Terhadap Kinerja Guru Sekolah Menengah Kejuruan Negeri Rumpun Bisnis Sekota Semarang. JURNAL STIE SEMARANG (EDISI ELEKTRONIK), 5(2), 36-47.

Yani, A., \& Indrawati, A. (2016). Pengaruh lingkungan kerja dan motivasi kerja terhadap kompetensi guru bersertifikasi di SMK Negeri 1 Pasuruan. JPBM (Jurnal Pendidikan Bisnis dan Manajemen), 2(1), 58-74.

Yawan, R. (2016). Pengaruh motivasi kerja guru dan gaya kepemimpinan Kepsek terhadap kinerja guru SD Biak Numfor, Papua. Jurnal Pendidikan Matematika dan Sains, 4(2), 184-194.

Yodiq, M. (2016). Peran Komunikasi Interpersonal Kepala Sekolah terhadap Motivasi Kerja Guru di Sekolah Menengah Atas Islam Samarinda. Jurnal Ilmu Komunikasi, 4(2), 25.

How to cite this article:

Sriwahyuningsih. (2022). The Influence of Work Motivation and Interpersonal Communication on Social Competence of Public Elementary School Teachers in Cluster IV, Bukit Kapur District, Dumai City. Journal of Educational Sciences, 6(1), 92-106. 